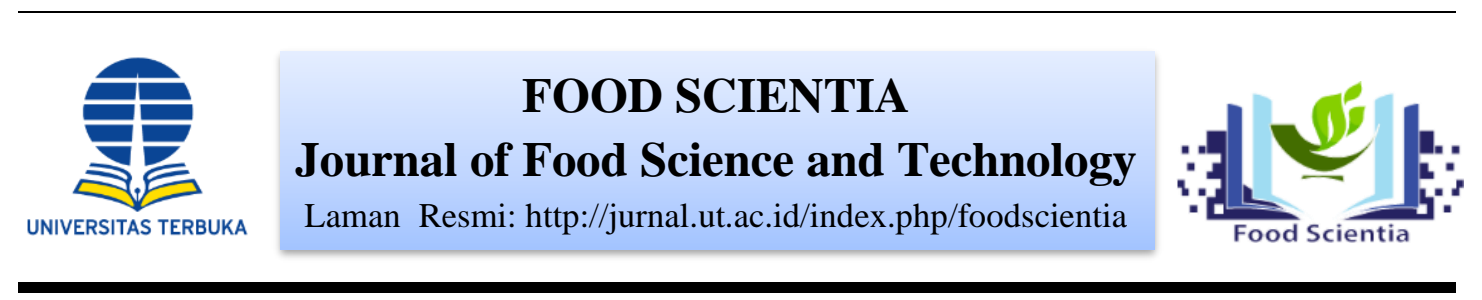

\title{
PENGARUH PENAMBAHAN EKSTRAK BAWANG PUTIH DAN CABAI PADA TELUR ASIN ITIK TERHADAP KANDUNGAN PROTEIN, TOTAL MIKROBA, DAN TINGKAT KESUKAAN KONSUMEN
}

\author{
Effect of Garlic and Chili Extracts Addition on Salted Duck Eggs \\ towards its Protein Content, Total Microbial, \\ Count and Consumer Hedonic Level
}

\author{
Sumarsih $^{1}$, Athiefah Fauziyyah ${ }^{2}$ \\ ${ }^{1}$ Program Studi Agroteknologi Fakultas Pertanian \\ Universitas Muhamammadiyah Yogyakarta \\ Jalan Brawijaya Tamantirto Kasihan Bantul Yogyakarta, 55183, Indonesia \\ ${ }^{2}$ Program Studi Teknologi Pangan Fakultas Sains dan Teknologi Universitas Terbuka \\ Jalan Pondok Cabe Raya Ciputat, Tangerang Selatan, 15418, Indonesia \\ e-mail: sumarsih1506@gmail.com
}

DOI: $10.33830 /$ fsj.v1i1.1452.2021

Diterima: 4 Maret 2021, Diperbaiki: 4 Juni 2021, Disetujui: 10 Juni 2021

\begin{abstract}
This study is aimed to determine the effect of garlic and chili extracts addition towards the protein content, total microbial count and consumer hedonic level of salted duck eggs. This study was conducted using Completely Randomized Design (CRD) with 3 treatments and repeated three times. The treatments tested were the addition of 100\% garlic extract and 50\% garlic: 50\% chili with subsequent 7 days ripening and 3 days incubation period. The parameters observed were protein content, total microbial count and consumer hedonic level. The data was statistically analyzed using analysis of variance (ANOVA) with 5\% significance level and further processed with Duncan's Multiple Range Test (DMRT) for those significantly different treatments. The results shows that the addition of 50\% garlic and 50\% chili extracts followed by 7 days ripening and 3 days incubation exhibit an elevated protein content on the salted duck eggs without any significant effect on its physical appearance, color, texture as well as the total microbial count.
\end{abstract}

Keywords: salted eggs, protein, garlic, total microbial count, hedonic level 


\begin{abstract}
ABSTRAK
Penelitian ini bertujuan untuk mengetahui pengaruh penambahan ekstrak bawang putih dan cabai pada telur asin itik terhadap kandungan protein, total mikroba dan tingkat kesukaan konsumen. Metode penelitian memakai metode eksperimen Rancangan Acak Lengkap (RAL) faktor tunggal menggunakan 3 variabel perlakuan dan tiap perlakuan diulang tiga (3) kali. Perlakuan yang diujikan adalah penambahan ekstrak bawang putih $100 \%$ dan bawang putih-cabai dengan perbandingan 50\% : 50\% dengan waktu pemeraman 7 hari dan inkubasi 3 hari. Parameter yang diamati merupakan kadar protein, total mikroba, dan tingkat kesukaan konsumen. Analisis data hasil penelitian memakai teknik analisis sidik ragam ANOVA 5\% dan uji lanjut Duncan's Multiple Range Test (DMRT). Hasil penelitian menunjukan penambahan ekstrak bawang putih dan cabai dengan perbandingan 50\% : 50\% pada pemeraman 7 hari dan inkubasi 3 hari dapat meningkatkan nilai gizi protein telur asin, namun tidak dapat meningkatkan tampilan fisik baik warna, tekstur dan kenampakan serta jumlah mikroba.
\end{abstract}

Kata Kunci : telur asin, nilai gizi protein, bawang putih, total mikroba, faktor kesukaan konsumen

\title{
PENDAHULUAN
}

Itik merupakan salah satu jenis telur yang telah banyak dikonsumsi oleh masyarakat Indonesia. Hal ini dapat dilihat dari jumlah konsumsi telur itik yang semakin meningkat dari tahun ke tahun. Seperti pada tahun 2019 konsumsi telur itik mencapai 328.686,53 ton (BPS, 2019). Dan pada tahun 2020 konsumsi telur meningkat mencapai 332.907,32 ton (BPS, 2020).

Telur itik adalah sumber protein hewani yang mengandung asam amino lengkap dan protein relatif tinggi. Telur itik juga mengandung senyawa yang diperlukan oleh tubuh antara lain mineral, vitamin B6, asam pantotenat, tiamin, vitamin A, vitamin E, niasin dan vitamin B12 (Purdiyanto \& Riyadi, 2018)

Telur itik tidak mengenal musim, tetapi mempunyai kelemahan yaitu rentan mengalami kerusakan baik fisik, kimia maupun biologi (mikroba). Pada umumnya kerusakan secara biologi pada telur disebabkan oleh bakteri. Kandungan protein dan kadar air yang cukup tinggi pada telur dapat menjadi media yang baik untuk pertumbuhan bakteri. Salah satu faktor pendukung tumbuhnya bakteri di dalam telur adalah faktor lama penyimpanan pada suhu kamar dan kandungan zat gizi. Hal tersebut dapat dimanfaatkan mikroba untuk pertumbuhan. Pangan yang berasal dari ternak mempunyai cemaran mikroba yang dapat membahayakan kesehatan manusia 
antara lain Escherichia coli, Coliform, Staphylococcus aureus, Enterococci, Salmonella sp., Clostridium sp., Champhylobacter sp., dan Listeria sp. (Finata et al., 2015). Hal tersebut dapat berpengaruh terhadap mutu dan kualitas yang berpengaruh terhadap keawetan telur. Perlu upaya untuk menjaga mutu telur selama pengolahan dan penyimpanan.

Metode pengasinan adalah metode yang banyak dilakukan oleh masyarakat sebagai upaya untuk mengawetkan telur. Ada dua metode pembuatan telur asin yang dapat dilakukan yaitu: 1) Perendaman memakai larutan garam jenuh dingin selama 7 hari. Penambahan garam pada proses ini adalah untuk memberikan rasa asin pada telur dan sebagai bahan pengawet. 2) Pemeraman dengan cara membungkus telur menggunakan adonan dan diperam selama 7 hari. Setelah proses pemeraman selesai, adonan segera dilepas dari kulit telur agar rasa asin tidak menjadi berlebihan (Ardiansyah, 2016).

Telur asin yang banyak dikonsumsi masyarakat selama ini hanya telur asin biasa yaitu telur asin yang memiliki putih telur yang rasanya lebih asin, sedangkan kuning telurnya memiliki rasa yang lebih gurih tanpa adanya variasi rasa lainnya. Sehingga untuk mendapatkan rasa yang berbeda pada telur asin adalah dengan menambahkan unsur rasa pada proses pembuatannya (Sari et al., 2014).

Bawang putih mengandung senyawa antibakteri. Salah satu senyawa yang memiliki efek antimikroba adalah allisin. Allisin dapat menghambat pertumbuhan gram positif dan garam negatif dengan cara menghambat produksi RNA dan sintesis lipid (Moulia et al., 2018)

Cabai mengandung bahan antioksidan antara lain vitamin E, vitamin C, seng, selenium, dan capsaicin. Bahan antioksidan pada cabai efektif untuk mengeliminasi radikal bebas. Penambahan cabai bisa memberikan warna merah dan cita rasa pedas, sedangkan penambahan bawang putih memberikan aroma yang khas rasa bawang putih (Saputra, 2017). Kombinasi penambahan ekstrak bawang putih dan cabai dapat menjadi alternatif varian rasa telur asin yang memiliki sifat mutu dan cita rasa yang lebih baik.

Berdasarkan penelusuran literatur dan jurnal penelitian, belum banyak diketahui tentang pengaruh pemberian bawang putih dan cabai terhadap kandungan 
gizi protein, total mikroba sebagai indikator keamanan pangan dan tingkat kesukaan konsumen, sehingga hal tersebut yang menjadi dasar melakukan penelitian ini.

\section{METODE PENELITIAN}

\section{Alat dan Bahan}

Alat yang digunakan terdiri dari timbangan, sendok, toples, baskom, pisau, gelas ukur, besek, saringan, jarum suntik, grinder, kertas label dan panci. Bahan yang digunakan terdiri dari telur itik segar, garam, abu gosok, bawang putih, cabai dan air.

\section{Rancangan Percobaan}

Dalam penelitian ini rancangan percobaan yang dipakai adalah Rancangan Acak Lengkap (RAL) faktor tunggal menggunakan tiga (3) variabel perlakuan dan tiap perlakuan diulang tiga (3) kali. Ketiga perlakuan menggunakan formulasi abu gosok (80\%) dan garam (20\%). Perlakuan yang diterapkan adalah sebagai berikut:

$\mathrm{A}=$ Tanpa ekstrak bawang putih dan ekstrak cabai

$\mathrm{B}=$ Penambahan ekstrak bawang putih $100 \%$

$\mathrm{C}=$ Penambahan ekstrak bawang putih $50 \%$ + ekstrak cabai $50 \%$

Ada 3 variabel perlakuan, setiap perlakuan diulang 3 kali, sehingga diperoleh 9 unit. Setiap unit terdiri dari 12 sampel, 1 sampel untuk uji kadar protein, 1 sampel untuk uji total mikroba, 8 sampel untuk uji tingkat kesukaan konsumen dan 2 sampel korban sehingga jumlah telur itik yang digunakan sebanyak 108 butir.

Tabel. 1. Formulasi perlakuan pada penelitian

\begin{tabular}{ccc}
\hline $\begin{array}{c}\text { Perlakuan yang } \\
\text { Diterapkan }\end{array}$ & Ekstrak bawang putih & Ekstrak cabai \\
\hline A & $0 \%$ & $0 \%$ \\
B & $100 \%$ & $0 \%$ \\
C & $50 \%$ & $50 \%$ \\
\hline
\end{tabular}

Hipotesis yang diuji pada penelitian ini adalah pengaruh penambahan ekstrak bawang putih dan cabai terhadap nilai gizi protein telur asin serta pengaruh bawang putih dan cabai sebagai anti mikroba terhadap total mikroba dan tingkat kesukaan konsumen. Pengaruh penambahan ekstrak bawang putih dan cabai diduga mempengaruhi nilai gizi protein telur asin. Data hasil penelitian dianalisis memakai 
teknik analisis sidik ragam ANOVA 5\% dan uji lanjut Duncan's Multiple Range Test (DMRT).

\section{Prosedur Pengujian}

\section{Proses Pembuatan Telur Asin Itik Metode Pemeraman}

Proses pembuatan telur asin metode pemeraman adalah (1) sortasi telur itik yaitu dengan memilih telur yang bermutu baik, (2) mencuci telur menggunakan air mengalir sampai bersih kemudian keringkan, (3) membuat adonan pasta abu garam dengan perbandingan $4: 1$ /abu 80\% : garam 20\% dan tambahkan air secukupnya, (4) Bungkus satu persatu seluruh permukaan telur secara merata dengan adonan pasta abu garam, (5) simpan telur pada besek agar kering sehingga air tidak menggenang dan letakkan ditempat yang bersih serta terbuka selama 7 hari, (6) setelah 7 hari bersihkan telur asin dari adonan.

\section{Proses Pembuatan Telur Asin Variasi Rasa dengan Metode Injeksi}

Proses pembuatan telur asin variasi rasa metode injeksi adalah (1) Pengupasan bawang putih dan cuci, (2) Pengupasan cabai dan cuci, (3) Penimbangan bawang putih sebesar 100 gram, hancurkan dengan menggunakan grinder dan tambahkan $100 \mathrm{ml}$ air kemudian disaring untuk diambil ekstraknya/perlakuan B, (4) Penimbangan bawang putih dan cabai masing-masing sebesar 50 gram, hancurkan menggunakan grinder dan tambahkan $100 \mathrm{ml}$ kemudian disaring untuk diambil ekstraknya/perlakuan C, (5) Penyiapan telur asin hasil pemeraman 7 hari dan injeksi dengan ekstrak bawang putih 100\% pada perlakuan B dan ekstrak bawang putih cabai dengan perbandingan 50\%: 50\% pada perlakuan C, (6) Telur asin perlakuan A adalah kontrol yaitu telur asin pemeraman 7 hari tanpa penambahan ekstrak bawang putih dan cabai, (7) Penyimpanan telur asin ke dalam toples selama 3 hari, (8) Setelah itu rebus telur asin dengan api kecil selama 30 menit.

\section{Uji Kadar Protein}

Uji kadar protein dilakukan dengan cara menguji kadar nitrogen dalam sampel, hasilnya dikonversi dengan mengalikan kadar nitrogen yang diperoleh dengan faktor koreksi sebesar 6,25. Hasil konversi tersebut merupakan kandungan protein dalam sampel. Uji kadar nitrogen dilakukan dengan metode Kjeldahl dengan 
cara kerja sebagai berikut: (1) Sampel dihaluskan dan timbang sebanyak 0,2 gram, kemudian dimasukkan dalam labu kjeldahl, (2) Tambahkan katalis $\mathrm{N}$ sebanyak 0,7 gram (5 gram $\mathrm{CuSO}_{4}+250$ gram $\mathrm{Na}_{2} \mathrm{SO}_{4}+0,7$ gram Selenium/TiO 2 ), (3) Tambahkan $\mathrm{H}_{2} \mathrm{SO}_{4}$ pekat sebanyak $4 \mathrm{ml}$, selanjutnya didestruksi dalam almari asam sampai warna berubah menjadi hijau jernih, (4) Dinginkan dan tambahkan $10 \mathrm{ml}$ aquadest, (5) Destilasi dengan menambahkan $\mathrm{NaOH}-\mathrm{TiO}_{2}\left(\mathrm{NaOH} 40 \%+\mathrm{Na}_{2} \mathrm{~S}_{2} \mathrm{O}_{3}\right.$ $5 \%$ ) sebanyak $20 \mathrm{ml}$ dan destilat di tampung menggunakan $\mathrm{H}_{3} \mathrm{BO}_{3} 4 \%$ yang telah di beri indikator MrBCG, sampai destilat mencapai volume $60 \mathrm{ml}$ ditandai dengan perubahan warna dari merah menjadi biru, (6) Setelah volume mencapai $60 \mathrm{ml}$, destilasi dihentikan kemudian destilat di titrasi menggunakan larutan standar $\mathrm{HCl}$ 0,02 N sampai warna berubah dari biru menjadi merah muda (Hasanah, 2015). Volume titrasi dicatat dan dihitung kadar protein dengan rumus sebagai berikut:

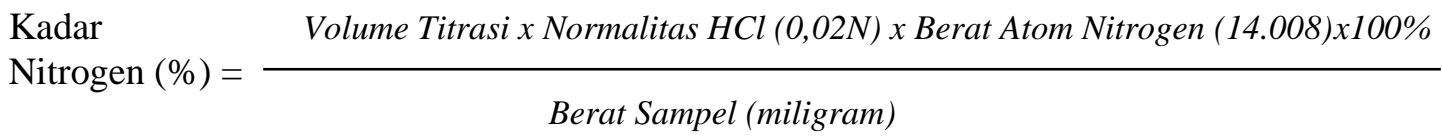

Kadar Protein $(\%)=$ Kadar nitrogen $\mathrm{x}$ faktor konversi $(6.25)$

\section{Uji Total Mikroba}

Penghitungan jumlah mikroba di dalam suatu suspensi atau bahan dapat dilakukan dengan banyak cara. Salah satu cara untuk menghitung jumlah sel adalah dengan cara total plate count. Pengamatan pada penelitian ini dilakukan pada tiga telur yang diasinkan untuk masing-masing perlakuan. Sampel putih dan kuning telur dihaluskan dan dihomogenkan dalam wadah steril, sampel yang telah homogen tersebut diencerkan pada pengenceran $10^{-1}$ dengan cara mencampurkan satu gram telur dilarutkan dalam $9 \mathrm{ml}$ larutan akuades steril dalam tabung reaksi. Pengenceran dibuat sampai $10^{-6}$ dengan cara yang sama. Penanaman sampel pada media Plate Count Agar (PCA) dengan metode sebar. Larutan pengenceran $10^{-4}$ sampai dengan $10^{-6}$ diambil menggunakan mikropipet sebanyak $0,1 \mathrm{ml}$ dengan tiga kali ulangan yang terlebih dahulu dihomogenkan menggunakan vortex selanjutnya diinokulasikan di atas permukaan media PCA dengan metode sebar. Perataan inokulum dilakukan menggunakan drigalsky di atas api bunsen agar steril, kemudian inkubasi pada suhu $37^{\circ} \mathrm{C}$ selama 24 jam pada posisi cawan petri terbalik. Koloni yang tumbuh dihitung menggunakan colony counter. Variabel yang diamati adalah jumlah total mikroba 
pada sampel telur asin. Jumlah koloni bakteri dari sampel dihitung dengan menggunakan rumus sebagai berikut (Soesetyaningsih \& Azizah, 2020):

1

Koloni /gr $=\Sigma$ koloni per cawan $\mathrm{x} \longrightarrow C F U / g r$

\section{Uji Hedonik}

faktor pengenceran

Uji hedonik yang dilakukan mencakup pengujian terhadap atribut warna, rasa, aroma, tekstur dan kenampakan bagian putih dan kuning telur asin. Pengujian hedonik ini tersaji pada 30 panelis semi terlatih (Sari et al., 2014). Panelis terdiri dari dosen, tenaga kependidikan dan mahasiswa Fakultas Pertanian Universitas Muhammadiyah Yogyakarta dengan memberikan penilaian kesukaan konsumen terhadap sampel telur asin. Pengujian ini menggunakan metode skoring dan range nilai dari 1-5 menggunakan skala penilaian sebagai berikut: (1) sangat tidak suka, (2) tidak suka, (3) netral, (4) suka, (5) sangat suka (Rahmi et.al, 2013)

\section{Analisis Data}

Hasil pengamatan dianalisis menggunakan uji sidik ragam atau Analysis of Variance (ANOVA) pada $\alpha=5 \%$ dan jika didapatkan hasil yang berbeda nyata maka dilakukan uji lanjut menggunakan Duncan's Multiple Range Test (DMRT) untuk mendapatkan hasil yang terbaik.

\section{HASIL DAN PEMBAHASAN}

\section{Uji Kadar Protein}

Hasil uji kadar protein telur asin dengan penambahan ekstrak bawang putih dan cabai bisa dilihat pada tabel 2 .

Tabel 2. Hasil Uji Duncan's Multiple Range Test (DMRT) Pengaruh Penambahan Ekstrak Bawang Putih dan Cabai pada Telur Asin Itik Terhadap Kandungan Protein

\begin{tabular}{cc}
\hline Perlakuan & Rerata \\
\hline A & $12,33^{\mathrm{b}}$ \\
B & $12,48^{\mathrm{b}}$ \\
C & $12,79^{\mathrm{a}}$
\end{tabular}

Keterangan : Angka yang di ikuti oleh huruf yang berbeda pada kolom yang sama menunjukkan beda nyata pada taraf $5 \%$. 
Tabel 2 menunjukkan perlakuan $\mathrm{C}$ (penambahan ekstrak bawang putih dan cabai dengan perbandingan 50\%:50\%) memiliki rata rata kadar protein yang paling tinggi dibandingkan dengan perlakuan B (penambahan ekstrak bawang putih 100\%) dan A (tanpa penambahan ekstrak bawang putih dan cabai/kontrol). Berdasarkan hasil uji analisis sidik ragam (ANOVA) pada $\alpha=5 \%$, penambahan ekstrak bawang putih dan cabai berpengaruh sangat nyata terhadap kadar protein. Kadar protein telur asin pada penelitian ini mendukung hasil penelitian sebelumnya yang dilaporkan oleh beberapa peneliti dimana telur itik asin pada pemeraman hari ketujuh memiliki kandungan protein 12,47 \% (Salim et al., 2017). Hasil uji lanjut DMRT pada penelitian ini diperoleh perlakuan terbaik pada perlakuan $\mathrm{C}$ dengan rerata kadar protein sebesar $12,79 \%$, kadar protein yang diperoleh lebih tinggi dari perlakuan tanpa penambahan ekstrak bawang putih dan cabai, hal ini dikarenakan adanya kandungan protein pada bawang putih dan cabai yang ditambahkan.

\section{Uji Total Mikroba}

Hasil uji total mikroba telur asin dengan penambahan ekstrak bawang putih dan cabai bisa dilihat pada Tabel 3 .

Tabel 3. Hasil Uji Pengaruh Penambahan Ekstrak Bawang Putih dan Cabai pada Telur Asin Itik Terhadap Total Mikroba Transformasi log Y

\begin{tabular}{cccc}
\hline \multirow{2}{*}{ Perlakuan } & I & Ulangan & II \\
\hline A & $6,45^{\mathrm{a}}$ & $6,08^{\mathrm{a}}$ & $5,70^{\mathrm{a}}$ \\
$\mathrm{B}$ & $6,45^{\mathrm{a}}$ & $5,00^{\mathrm{a}}$ & $5,60^{\mathrm{a}}$ \\
$\mathrm{C}$ & $5,30^{\mathrm{a}}$ & $6,11^{\mathrm{a}}$ & $6,15^{\mathrm{a}}$ \\
\hline
\end{tabular}

Tabel 3 menunjukkan perlakuan A (tanpa penambahan ekstrak bawang putih dan cabai/kontrol) memiliki rata rata jumlah TPC yang hampir sama dengan perlakuan yang diberikan penambahan ekstrak bawang putih dan cabai yaitu B (penambahan ekstrak bawang putih 100\%) dan C (penambahan ekstrak bawang putih dan cabai dengan perbandingan 50\%:50\%). Berdasarkan hasil uji analisis sidik ragam (ANOVA) pada $\alpha=5 \%$, jumlah mikroba dari ketiga sampel tidak berbeda nyata dengan adanya pengaruh penambahan ekstrak bawang putih dan cabai, hal ini 
menunjukkan bahwa perlakuan dengan penambahan ekstrak bawang putih dan cabai tidak berpengaruh terhadap telur asin yang dihasilkan sehingga telur asin tetap aman untuk dikonsumsi seperti halnya pada perlakuan kontrol.

\section{Uji Hedonik}

Hasil uji hedonik telur asin dengan pengaruh penambahan ekstrak bawang putih dan cabai pada parameter aroma dan rasa bisa dilihat pada Tabel 4.

Tabel 4. Hasil Uji Duncan's Multiple Range Test (DMRT) Pengaruh Penambahan Ekstrak Bawang Putih dan Cabai pada Telur Asin Itik Terhadap Aroma dan Rasa

\begin{tabular}{crc}
\hline Perlakuan & Aroma & \multicolumn{1}{c}{ Rasa } \\
\hline A & $3,30^{\mathrm{a}}$ & $3,22^{\mathrm{a}}$ \\
B & $2,43^{\mathrm{b}}$ & $2,50^{\mathrm{b}}$ \\
C & $2,40^{\mathrm{b}}$ & $2,24^{\mathrm{b}}$
\end{tabular}

Keterangan : Angka yang diikuti oleh huruf yang berbeda pada kolom yang sama menunjukkan beda nyata pada taraf $5 \%$

Tabel 4 menunjukkan perlakuan A (tanpa penambahan ekstrak bawang putih dan cabai/kontrol) memiliki nilai skor aroma dan rasa yang paling tinggi dibandingkan dengan perlakuan B (penambahan ekstrak bawang putih 100\%) dan C (penambahan ekstrak bawang putih dan cabai dengan perbandingan 50\%:50\%). Berdasarkan hasil uji analisis sidik ragam (ANOVA) pada $\alpha=5 \%$, perlakuan tanpa penambahan ekstrak bawang putih dan cabai berpengaruh nyata terhadap aroma dan rasa. Hasil uji lanjut DMRT pada penelitian ini diperoleh perlakuan terbaik pada sampel A (tanpa penambahan ekstrak bawang putih dan cabai), hal ini dikarenakan konsumen lebih menyukai telur asin itik yang memiliki aroma dan rasa original.

Hasil uji hedonik telur asin dengan pengaruh penambahan ekstrak bawang putih dan cabai pada parameter warna putih telur, warna kuning telur, tekstur dan kenampakan dapat dilihat pada Tabel 5. 
Tabel 5. Hasil Uji Hedonik Pengaruh Penambahan Ekstrak Bawang Putih dan Cabai pada Telur Asin Itik Terhadap Warna Putih Telur, Warna Kuning Telur, Tekstur dan Kenampakan

\begin{tabular}{cllll}
\hline Perlakuan & $\begin{array}{c}\text { Warna Putih } \\
\text { Telur }\end{array}$ & $\begin{array}{c}\text { Warna } \\
\text { Kuning } \\
\text { Telur }\end{array}$ & Tekstur & Kenampakan \\
\hline A & $3,40^{\mathrm{a}}$ & $3,10^{\mathrm{a}}$ & $3,30^{\mathrm{a}}$ & $3,18^{\mathrm{a}}$ \\
$\mathrm{B}$ & $3,04^{\mathrm{a}}$ & $2,20^{\mathrm{a}}$ & $2,71^{\mathrm{a}}$ & $2,65^{\mathrm{a}}$ \\
$\mathrm{C}$ & $3,04^{\mathrm{a}}$ & $2,72^{\mathrm{a}}$ & $2,55^{\mathrm{a}}$ & $2,74^{\mathrm{a}}$ \\
\hline
\end{tabular}

Tabel 5 menunjukkan perlakuan A (tanpa penambahan ekstrak bawang putih dan cabai/kontrol) memiliki nilai skor yang hampir sama pada parameter warna putih telur, warna kuning telur, tekstur dan kenampakan dengan perlakuan yang diberikan penambahan ekstrak bawang putih dan cabai yaitu B (penambahan ekstrak bawang putih 100\%) dan C (penambahan ekstrak bawang putih dan cabai dengan perbandingan 50\%:50\%). Berdasarkan hasil uji analisis sidik ragam (ANOVA) pada $\alpha=5 \%$ pada parameter warna putih telur, warna kuning telur, tekstur dan kenampakan tidak ada beda nyata pada semua perlakuan, hal ini menunjukkan secara fisik tidak ada perbedaan antara perlakuan dengan penambahan ekstrak bawang putih dan cabai maupun perlakuan tanpa penambahan ekstrak bawang putih dan cabai karena hal ini yang mempengaruhi faktor kesukaan konsumen adalah aroma dan rasa.

\section{KESIMPULAN DAN SARAN}

Berdasarkan pembahasan pada penelitian ini dapat disimpulkan bahwa pengaruh penambahan ekstrak bawang putih dan cabai pada telur asin itik dengan perbandingan 50\%:50\% pada pemeraman 7 hari dan inkubasi 3 hari dapat meningkatkan kadar protein telur asin, namun tidak dapat meningkatkan jumlah mikroba serta faktor kesukaan konsumen. Penelitian lebih lanjut perlu dilakukan dengan jumlah waktu penyimpanan dan konsentrasi bawang putih serta cabai yang bervariasi. 


\section{DAFTAR PUSTAKA}

Ardiansyah. (2016). Pertumbuhan Salmonella Sp. Dengan Variasi Konsentrasi Bawang Putih (Allium Sativum) Pada Telur Asin. Skripsi. Ilmu Peternakan Fakultas Sains dan Teknologi UIN Alauddin Makassar.

Badan Pusat Statistik. (2020). Produksi Telur Itik/Itik Manila Menurut Provinsi (Ton) 2018-2020. Jakarta. Badan Pusat Statistik.

Finata, R. P., M. D. Rudyanto, dan I. G. K. Suarjana. (2015). Pengaruh lama penyimpanan pada suhu kamar telur itik segar dan telur yang mengalami pengasinan ditinjau dari jumlah Eschericia coli. Buletin Veteriner Udayana, 7 (1).

Hasanah. U. (2015). Penetapan Kadar Protein pada Biskuit dengan Metode Kjeldahl. Tugas Akhir. Program Diploma III Analis Farmasi dan Makanan Fakultas Farmasi Universitas Sumatera Utara.

Moulia, M. N., Syarief, R., Iriani, E. S., Kusumaningrum, H. D., \& Suyatma, N. E. (2018). Antimikroba Ekstrak Bawang Putih. Jurnal Pangan, 27(1), 55-66.

Purdiyanto, J., \& Riyadi, S. (2018). Pengaruh Lama Simpan Telur Itik Terhadap Penurunan Berat, Indeks Kuning Telur (IKT),dan Haugh Unit (HU). Jurnal Maduranch, 3(1)(1), 23-28.

Rahmi, A., Susi, \& Agustina, L. (2013). Analisis Tingkat Kesukaan Konsumen, Penetapan Umur Simpan Dan Analisis Kelayakan Usaha Dodol Pisang Awa. Jurnal ZIRAA'AH, 37(2), 26-32.

Salim, E., Syam, H., Wijaya, M. (2017). Pengaruh variasi waktu pemeraman telur asin dengan penambahan abu sabut kelapa terhadap kandungan kadar klorida, kadar protein dan tingkat kesukaan konsumen. Jurnal Pendidikan Teknologi Pertanian, 3 (2): 107-116.

Saputra. A., F. S. Mumpuni, E. Setiadi, I. D. Setiawan. (2019). Kinerja pertumbuhan dan sintasan benih ikan baung (Hemibagrus nemurus) yang diberi probiotik berbeda. Jurnal Mina Sains 5 (1).

Saputra, A. T. (2017). Kualitas Telur Asin pada Pemberian Bawang Putih (Allium sativum) dengan cabai (Capsicum annum L.) pada Lama Penyimpanan Berbeda. Skripsi. Fakultas Peternakan Universitas Hasanuddin Makassar. 
Sari D. K, S. A. Marliyati, L. Kustiyah , A. Khomsa , T. M. Gantohe. (2014). Uji organoleptik formulasi biskuit fungsional berbasis tepung ikan gabus (Ophiocephalus striatus). Jurnal Agritech, 34 (2).

Soesetyaningsih, Azizah. (2020). Akurasi perhitungan bakteri pada daging sapi menggunakan metode hitung cawan. Berkala Sainstek, VIII (3): 75-79. 